\title{
Effect of Different Land-Use Patterns on Soil Fertility Characteristics
}

\author{
Hui LIU ${ }^{1}$, Chang-quan WANG ${ }^{2}$, Mei YANG ${ }^{2}$, Shang-chun XIE ${ }^{1} \&$ Lei WANG ${ }^{3}$ \\ ${ }^{1}$ Chengdu Agricultural Technology Vocational College, Chengdu, Sichuan, PR China \\ ${ }^{2}$ College of Resources and Environment, Sichuan Agricultural University, PR China \\ ${ }^{3}$ Territory Resources Bureau of Ziyang, Second Ring Road Crossroads of Ziyang Avenue, ZiYang, Sichuan, PR \\ China \\ Correspondence: WANG, Chang-quan, College of Resources and Environment, Sichuan Agricultural University, \\ PR China. Tel: 86-136-0826-9831. E-mail: w.changquan@163.com
}

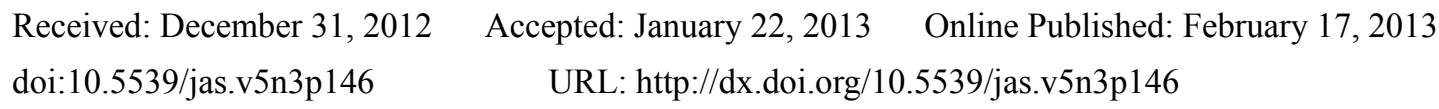

\begin{abstract}
In this paper, a field survey and analysis about the fertility of cultivated layer soil for various usage in Wen Jiang District was carried out. The main results were as follows: the content of organic matter in the cultivated layer of sodded soil has a slight increase. The content of soil alkaline hydrolysis $\mathrm{N}$ was positively correlated with the content of soil organic matter. The content of available $\mathrm{P}$ and available $\mathrm{K}$ decreased after forestation or sodding. After paddy soil was transformed to garden, the soil fertility was affected in some extent. If the soil was fertilized properly, especially when prescription fertilization was adopted, the variety of soil properties was small and there was no evident obstacle in resuming rice planting, especially for the soil that was used to replant deciduous shrubbery. So far as retaining soil fertility was paid attention to, most of the transformed soil could be resumed as before. So this land utilization mode was worth to be encouraged and extended at present stage.
\end{abstract}

Keywords: Wen Jiang district, cultivated land use patterns, soil fertility, sustainable utilization

\section{Introduction}

With the rapid development of the social economy, the national annually occupy a large number of agricultural land, and using extensive cultivated land-use patterns lead to a gradual decline in soil quality. Therefore, the sustainable use of cultivated land is the fundamental objectives of land resources development, utilization and protection. So it is particularly urgent to do research on the sustainable use of cultivated land resources. Up to now, there are a lot of researches on cultivated land resources and its utilizing pathways in China. Especially in Fujian Province, they had made a in-depth and systematic study on optimal use of cultivated land. However, there are few studies concerned about the cultivated land resources and its its utilizing pathways in Sichuan Province (Pang et al., 2004; Turner et al., 1995; Lambin et al., 1999; Lei et al., 2004).

In recent years, Wen Jiang Distinct developed a large number of "agritainment" to meet the consumer demand such as holiday leisure, catering and entertainment etc., and some nurseries has been established to meet the needs of greening, beautification and viewing. The transformation of agricultural production mode leads to the rapid changes in land use patterns, and it also brings new challenges for reasonable use of the cultivated land resources in Wen Jiang Distinct. Therefore, carrying out research about sustainable use of cultivated land resources in the study area has an important theoretical and practical significance for directing regional cultivated land resource utilization. At the same time, the study would serve "three rurals" better and help to construct a harmonious and prosperous socialism new countryside (Liu, 1999; Guo et al., 2001; Doran et al., 1994; Parr et al., 2004).

\section{Materials and Methods}

\subsection{General Situation of the Study Area}

Wen Jiang Distinct is located in southern of "Wen Pi Du" national ecological demonstration zone which is the first contiguous construction in China. And it also lies in the second economic layer of Chengdu city. The region covering an area of 277 square kilometers, with a total population of 326,700.The economy of the whole district is developing very fast.Wen Jiang Distinct belongs to Min Jiang alluvial plain, without mountains or hills. And it is belongs to subtropical humid climate zones, four distinct seasons, mild climate with 281 days frost-free period, moreover with aspect of rivers, abundant rainfall and rich resources, and was called'Tian Fu'for its self-sufficient 
and strategical strategic position. It belongs to the world-famous "Du Jiang Yan irrigation area", and it is a well-known township of flowers, trees, garlic and small poultry. It is abundant in paddy rice, wheat, canola and vegetables. It is well known for its beautiful name "golden Wen Jiang".

\subsection{Collection, Determination and Distribution Scheme of Soil Samples}

22 sampling unit were confirmed according to the differences between planting patterns (paddy soil of paddy-upland rotation, planting sod, evergreen and deciduous seedlings) and the difference among cultivation years (more than 5 years and less than 5 years). Each sampling unit collects 3 soil samples, and in total 66 soil samples were collected. Each sample was collected by using multi-point mixed sampling method, and then analysis and determination. selecting typical paddy soil samples as comparison, the rest were nursery soil, soil of different planting types or different planting years. The Specific instructions of sampling are shown in Table 1 to 4 .

Table 1. The explain of comparison soil sampling

\begin{tabular}{ll}
\hline Type & Paddy soil Comparison (Sample ID) \\
\hline Rice-garlic rotation (0-1) & paddy soil of rice-garlic rotation \\
Rice-canola rotation (0-2) & paddy soil of rice-canola crop rotation \\
\hline
\end{tabular}

Note: collected 3 samples each unit, the area of each unit was larger than 10mu.

Table 2. The explain of soil sampling under evergreen trees

\begin{tabular}{|c|c|c|}
\hline \multirow{2}{*}{$\begin{array}{l}\text { The main nursery } \\
\text { stock (ID) }\end{array}$} & \multicolumn{2}{|c|}{ cultivation years of Nursery stock (Sample ID) } \\
\hline & Planted less than 5 years & Planted more than 5 years \\
\hline privet (1) & $\begin{array}{l}1-1 \text { nurseries (mainly plant privet) between } 3 \\
\text { and } 5 \text { years }\end{array}$ & $\begin{array}{l}\text { 1-2 nurseries (mainly plant privet) more } \\
\text { than } 5 \text { years }\end{array}$ \\
\hline $\begin{array}{l}\text { Ficus } \\
\text { microcarpa }(2)\end{array}$ & $\begin{array}{l}2-1 \text { nurseries (mainly plant ficus microca } \\
\text { between } 3 \text { and } 5 \text { years }\end{array}$ & $\begin{array}{l}2-2 \text { nurseries (mainly plant ficus } \\
\text { microcarpa) more than } 5 \text { years }\end{array}$ \\
\hline Osmanthus (3) & $\begin{array}{l}\text { 3-1 nurseries (mainly plant Osmanthus) } \\
\text { between } 3 \text { and } 5 \text { years }\end{array}$ & $\begin{array}{l}\text { 3-2 nurseries (mainly plant Osmanthus) } \\
\text { more than } 5 \text { years }\end{array}$ \\
\hline Podocarpus (4) & $\begin{array}{l}4-1 \text { nurseries (mainly plant Podocarpus) } \\
\text { between } 3 \text { and } 5 \text { years }\end{array}$ & $\begin{array}{l}\text { 4-2 nurseries (mainly plant Podocarpus) } \\
\text { more than } 5 \text { years }\end{array}$ \\
\hline
\end{tabular}

Note: collected 3 samples each unit, the area of each unit was larger than $10 \mathrm{mu}$.

Table 3. The explain of soil sampling under hardwood

\begin{tabular}{|c|c|c|}
\hline \multirow{2}{*}{$\begin{array}{l}\text { The main nursery } \\
\text { stock (ID) }\end{array}$} & \multicolumn{2}{|c|}{ Nursery stock planting years(Sample ID) } \\
\hline & Planted less than 5 years & Planted more than 5 years \\
\hline redbud $t$ & $\begin{array}{l}5-1 \text { nurseries (mainly plant redbud tree, few } \\
\text { Osmanthus and Cinnamomum camphora) } \\
\text { between } 3 \text { and } 5 \text { years }\end{array}$ & $\begin{array}{l}5-2 \text { nurseries (mainly plant redbud tree, } \\
\text { Osmanthus) about } 8 \text { years }\end{array}$ \\
\hline ginkgo biloba(6) & $\begin{array}{l}\text { plant ginkgo biloba, } \\
\text { re than } 3 \text { years }\end{array}$ & $\begin{array}{l}\text { (mainly plant ginkgo biloba) } \\
\text { ars }\end{array}$ \\
\hline Cherry trees $(7)$ & $\begin{array}{l}7-1 \text { nurseries (mainly plant Cherry trees ) } \\
\text { between } 1 \text { and } 3 \text { years }\end{array}$ & $\begin{array}{l}7-2 \text { nurseries (mainly plant Cherry trees) } \\
\text { more than } 5 \text { years }\end{array}$ \\
\hline crape myrtle (8) & $\begin{array}{l}8-1 \text { nurseries (mainly plantCrape Myrtle) } \\
\text { between } 3 \text { and } 5 \text { years }\end{array}$ & $\begin{array}{l}\text { 8-2 nurseries (mainly plantCrape Myrtl, few } \\
\text { Evergreen species) more than } 7 \text { years }\end{array}$ \\
\hline Red maple (9) & $\begin{array}{l}9-1 \text { nurseries (mainly plant Red maple ) } \\
\text { between } 1 \text { and } 3 \text { years }\end{array}$ & $\begin{array}{l}9-2 \text { nurseries (mainly plant Red maple) more } \\
\text { than } 5 \text { years }\end{array}$ \\
\hline
\end{tabular}

Note: collected 3 samples each unit, the area of each unit was larger than 10mu. 
Table 4. The explain of soil sampling under sod

\begin{tabular}{lll}
\hline \multirow{2}{*}{ Type } & \multicolumn{2}{c}{ Sod planting years ( Sample ID) } \\
\cline { 2 - 3 } & \multicolumn{1}{c}{ Planted less than 5 years } & Planted more than 5 years \\
\hline Sod (10) & $\begin{array}{l}\text { 10-1 Planted sod between 2 and 5 years, } \\
\text { each area of the } 3 \text { fields was bigger than } \\
18 \mathrm{mu}\end{array}$ & $\begin{array}{l}10-2 \text { Planted sod more than } 5 \text { years, each } \\
\text { area of the } 3 \text { fields was bigger than 26mu }\end{array}$ \\
\hline
\end{tabular}

\subsection{Analysis Method}

Soil physical properties were measured by conventional method. The measurement items and methods of samples are shown in Table 5.

Table 5. The analysis method of soil properties

\begin{tabular}{ll}
\hline measurement items & methods \\
\hline soil moisture & drying method \\
soil organic matter & potassium dichromate volume - thermodilution method \\
soil alkali-hydrolysable $\mathrm{N}$ & diffusion method \\
soil available $\mathrm{P}$ & $0.05 \mathrm{~N} \mathrm{HCL}-0.025 \mathrm{~N} \mathrm{H}_{2} \mathrm{SO}_{4}$ extraction - (MADAC) \\
soil available P & $1 \mathrm{~mol} / \mathrm{L} \mathrm{NaNO} \mathrm{N}_{3}$ extraction - colorimetry method \\
\hline
\end{tabular}

\section{Results and Analysis}

\subsection{The Varying Characteristics of Soil Organic Matter under Different Land-Use Forms}

The determination results of soil organic matter by conventional methods were shown in Figure 1.

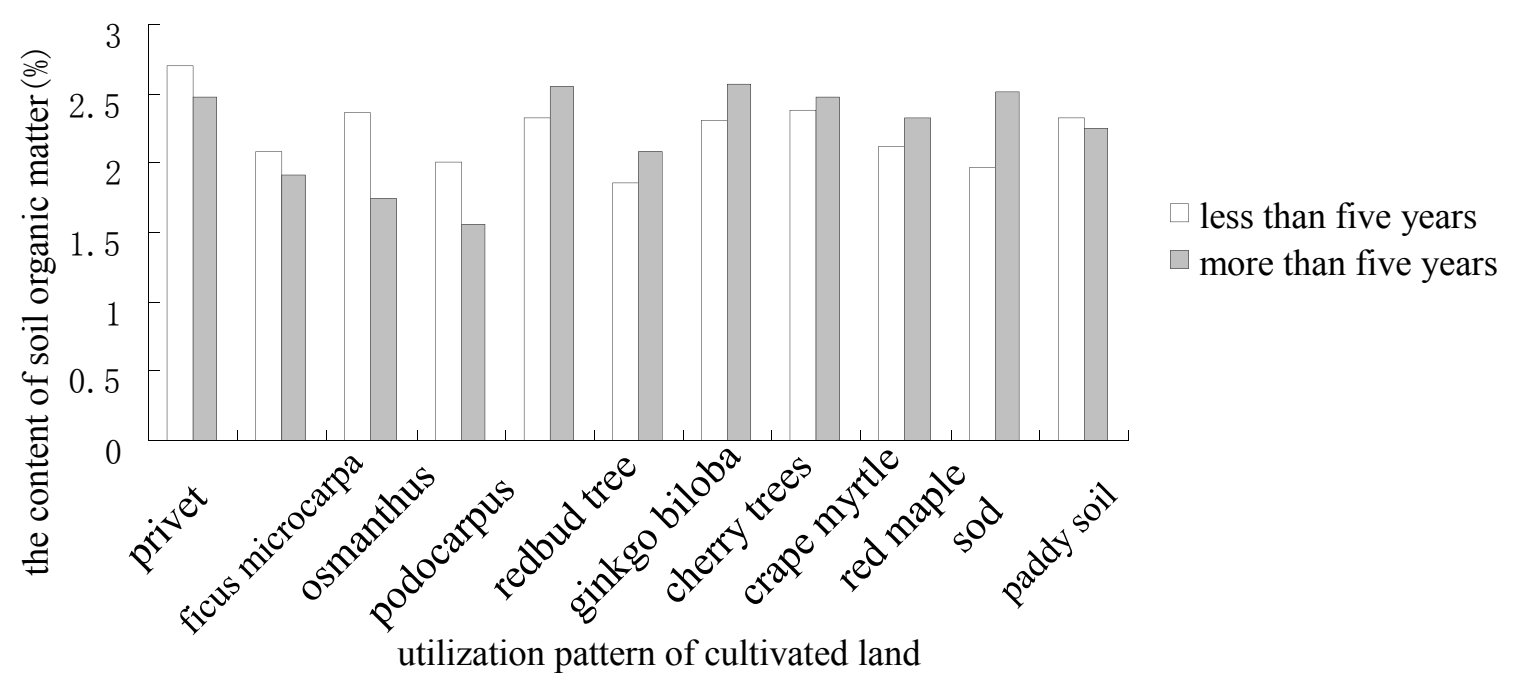

Figure 1. The content of soil organic matter

From Figure 1 we can know that the difference among the contents of soil organic matter under different land-use forms were not significant, the average content of organic matter in plough layer of paddy soil was $2.29 \%$. And the contents of soil organic matter in plough layer that replant seedlings and sod were $1.78 \sim 2.58 \%$ and $2.24 \%$. The contents of soil organic matter that replant nursery were different, that is because the nursery has different plant types or cultivation years. And the overall trend is that organic matter content decreased with the increase of the cultivation years of evergreen replant seedlings, especially the soil that replant osmanthus decreased most, by $0.62 \%$. With the increase the cultivation years of deciduous seedlings, organic matter content increased a little. 
The soil organic matter content in the plough layer that replant sod increase a little with the increase of cultivation years (Wang, 1999; Chen \& Yu, 2004). Compared with paddy soil which haven't change land use pattern, the soil organic matter content of which replant cherry trees, crape myrtle, redbud tree and privet increased slightly, while the soil organic matter content that replant podocarpus, ginkgo biloba, lobular banyan, osmanthus, red maple and sod droped slightly; the results shows that it has no obvious relationship with planting deciduous or evergreen seedlings.

\subsection{The Varying Characteristics of Soil Alkaline Hydrolysis $N$ under the Different Land-Use Forms}

From Figure 2 we can know that the average content of alkaline hydrolysis $\mathrm{N}$ in the plough layer of Paddy soil was $109.75 \mathrm{mg} \mathrm{kg}^{-1}$. However, the content of alkaline hydrolysis $\mathrm{N}$ in the soil that replant seedlings change a little, only 87.51 to $126.43 \mathrm{mg} \mathrm{kg}^{-1}$. And the contents of alkaline hydrolysis $\mathrm{N}$ in plough layer that replant sod was $88.27 \mathrm{mg}$ $\mathrm{kg}^{-1}$. Compared with paddy soil which haven't change land use pattern, the soil alkaline hydrolysis $\mathrm{N}$ content of which replanted red maple, cherry trees, crape myrtle, redbud tree and privet increased slightly (Luo et al., 2000; Wang et al., 2000; Xiao et al., 2005). However, all the soil alkaline hydrolysis $\mathrm{N}$ content that replant podocarpus, ginkgo biloba, lobular banya, osmanthus and sod decreased, especially in the soil that replant podocarpus, up to $22.23 \mathrm{mg} \mathrm{kg}^{-1}$. From the plants with different cultivation years, the alkaline hydrolysis $\mathrm{N}$ content that plant seedlings and sod over five years were slightly lower than which less than five years. But when plant deciduous seedlings (except the red maple) or under paddy-upland rotation, the alkaline hydrolysis $\mathrm{N}$ content in the soil that replant deciduous seedlings over five years were slightly higher than which less than five years. The cultivation years of the plants had the same impact on soil alkaline hydrolysis $\mathrm{N}$ as it does on soil organic matter.

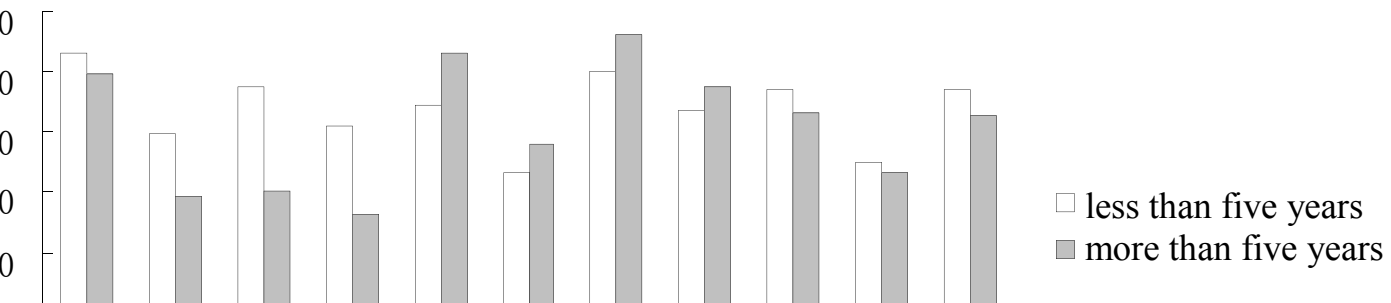

0

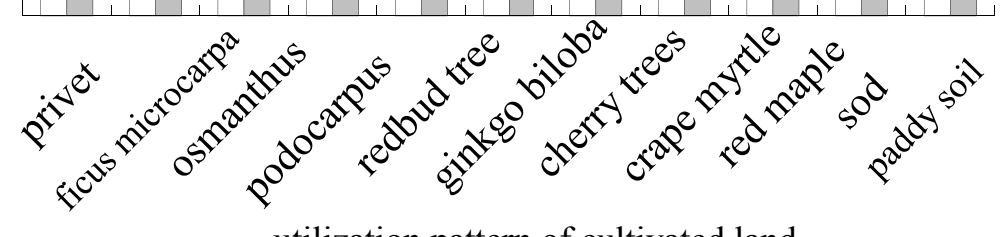

utilization pattern of cultivated land

Figure 2. The compare of soil alkaline hydrolysis $\mathrm{N}$

\subsection{The Varying Characteristics of Soil Available P under the Different Land-Use Forms}

From Figure 3 we can know that the average content of available $P$ in plough layer of of paddy soil is $22.11 \mathrm{mg} \mathrm{kg}^{-1}$. Due to the different types of planting seedlings, the soils differed greatly in available $\mathrm{P}$ content, were 17.81 to $42.60 \mathrm{mg} \mathrm{kg}^{-1}$. Among them the available $\mathrm{P}$ content in the soil that planted osmanthus fragrans is the highest, up to $42.60 \mathrm{mg} \mathrm{kg}^{-1}$; The average soil available $\mathrm{P}$ content in plough layer that replanted sod is $33.06 \mathrm{mg} \mathrm{kg}^{-1}$. Compared with paddy soil which haven't change land use pattern, there exist a great difference in the available P of soil that replanted seedings. After replanting seedlings in the paddy soil, the content of available $\mathrm{P}$ was increased . However, the content of soil available $\mathrm{P}$ was decreased after replanting some seedlings (such as crape myrtle, Podocarpus, cercis chinensis). The content of soil available $\mathrm{P}$ was increased after replanting sod (Wang et al., 2000; Xiao et al., 2005; Li et al., 2003). From the impact that different cultivation years had on available P of the soil under different land-use forms, the soil available P decreased slightly for planting the Ligustrum lucidum, the Ficus concinna and the Podocarpus, and the rest were increased, the highest rising comes from the soil for planting ginkgo, its available $P$ content is 1.5 times that of paddy soil. 


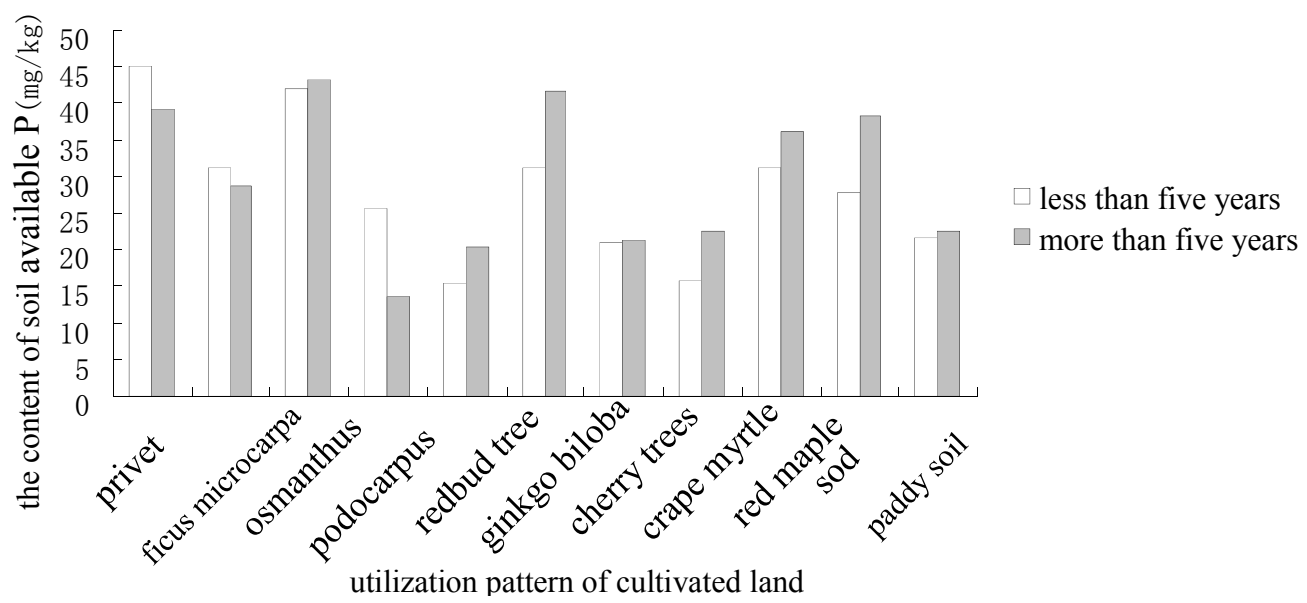

Figure 3. The compare of soil available $\mathrm{P}$

\subsection{The Varying Characteristics of Soil Available K under Different Land-Use Forms}

From Figure 4 we know that the average available $\mathrm{K}$ content in plough layer of paddy soil is $68.35 \mathrm{mg} \mathrm{kg}^{-1}$. Because of the different types of planted seedlings, the soil available $\mathrm{K}$ content in plough layer were quite different from each other, were 64.46 to $126.40 \mathrm{mg} \mathrm{kg}^{-1}$. And the soil available $\mathrm{K}$ content for replanting sod was $62.23 \mathrm{mg}$ $\mathrm{kg}^{-1}$. According to the impact that different cultivation years had on available $\mathrm{K}$ of the soil under different land-use forms, The impacts of planting different seedling on soil available $\mathrm{K}$ is not regular. The content of soil available $\mathrm{K}$ declined significantly after planting osmanthus, while the content of soil available $\mathrm{K}$ increased after replanted seedling (Xiao et al., 2005; Li et al., 2003;Wang et al., 1997). Compared with paddy soil which haven't change land use pattern, the content of soil available $\mathrm{K}$ for planting cherry trees and sod declined slightly, and the rest of them has risen slightly; The highest rising comes from the soil for planting ginkgo, it's available K content is twice that of paddy soil.

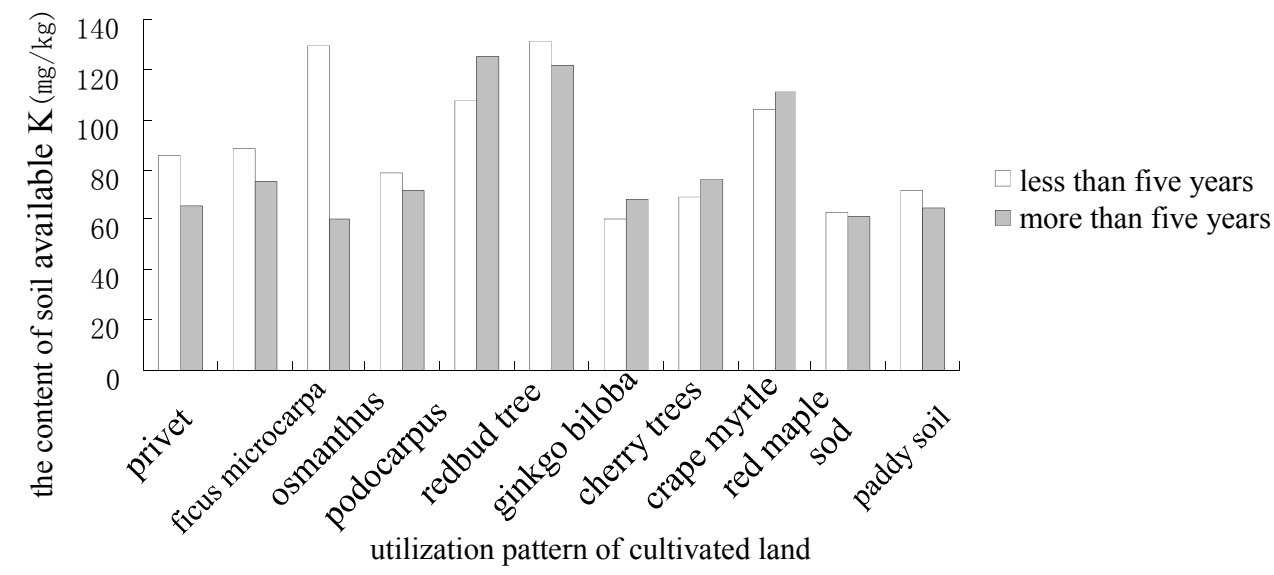

Figure 4. The compare of soil available $\mathrm{K}$

\section{Discussion}

The above analysis shows that: It has a certain influence on soil organic matter and soil nutrients after replanting seedlings or sod. Replanting seedlings or sod can improve the contents of soil organic matter and soil nutrients (Such as replanting red maple can improve most of the soil nutrients), from the changes of soil nutrients contents after replanting various kinds of seedlings or sod, the available soil nutrients varied greatly, while the changes of the soil organic matter.

\section{Conclusions}

(1) After replanting seedlings on paddy soil, the contents of soil organic matter were different for different plant types, but its rangeability was relatively small. with increase of the cultivation years of evergreen seedlings, the 
content of soil organic matter decreased; On the contrary, the content of soil organic matter increased with the increase of the cultivation years of deciduous seedlings. The content of soilalkaline hydrolysis $\mathrm{N}$ has a positive correlation with the content of soil organic matter, so their change rules were basically the same.

(2) The content of soil available P declined after replanting seedlings or sod on paddy soil, and the content of soil available $\mathrm{P}$ increased when replant some seedlings on paddy soil (such as privet, kahikatea, and so on). In most cases, the soil availabl $P$ tends to increase after replanting seedlings or sod.

(3) It has a certain influence on soil fertility after replanting seedlings or sod on paddy soil in Wenjiang district. Replanting some seedlings would reduce the soil quality, while some others would improve the soil quality. But all of these effects were not obvious, they were not a threat to soil quality and recovery of food production. The utilization of cultivated land resources in Wenjiang district should do the following aspects: In macroscopic view, we must ensure two unities (the unity of ecological and economic benefits, the unity of long-term and short-term interests); while in microscopic view, aimed to establish the benign circulation and balance of soil nutrients. In the utilization of cultivated land resources, the investment of organic fertilizer (green manure and base manure) should be increased to improve soil fertility which replanted seedlings or sod. All these measures would improve the health situation of soil.

\section{Acknowledgment}

This work was supported by two projects. They were "Research on the monitoring, evaluation and the technology avoid degradation of tobacco-planting soils in Sichuan province (2012008)" and "Integration and demonstration about the recycling technologies of poultry enterprise waste in the southwest of China (2012BAD14B18)".

\section{References}

Chen, Y. Q., \& Yu, J. Y. (2004). The evolution of red soil intrinsic properties using different ways. Chinese Journal of Soil Science, 35(2), 149-151.

Doran, J. W., Colernan, D. C., Bezdicek, D. F., \& Srewart, B. A. (1994). Defining soil quality for a sustainable environment. SSSA special publication, 35 .

Guo, X. D., Fu, B. J., \& Chen, L. D. (2001). low mountain hilly area cultivated land use on soil quality influence to ZunHua city in HeBei province as an example. Geography academic journal, 56(4), 447-454.

Lambin, E. F., Baes, X., \& Aockstael, N. (1999). Land-use and land-cover change[R]. Implementation Strategy. IGBP report No. 48, IHDP report No. 10.

Lei, H. M., Mou, Z. P., \& Wu, W. L. (2004). The innovation strategy of China's cultivated land resource sustainable utilization technology and system. Academic Journal of Hu Nan Agricultural University (Social Sciences Edition), 5(6), 10-14.

Li, T. X., Ma, G. R., Zhang, X. Z., \& Wang, C. Q. (2003). County level farmland nutrient balance and soil nutrient change trend research of purple hilly area. Journal of Soil and Water Conservation, 17(1), 103-106.

Liu, Y. S. (1999). Optimization of land use in the configuration of the application of the series model-in yueqing as an example. Geographical Scientific Progress, 18(1), 26-31.

Luo, M. W. Q., \& Chen, Q. J. (2000). Different amounts of nitrogen and phosphorus fertilizer to cotton soil microflora and the influence of their activity. Chinese Journal of Soil Science, 31(2), 66-69.

Nanjing Agricultural University edit chiefly (1998). Soil Agrochemistry Analysis (3rd ed.). Beijing: Agriculture Press.

Pang, Y., Zhang, Q. J., \& Ye, Y. G. (2004). Study on the Utilization Benefit of Cultivated Land in China. China Population, Resources and Environment, 14(5), 32-36.

Parr, J. F., Papendick, R., \& Homick, S. (1992). Soil Quality-the Key to a sustainable agriculture. American Journaly Alternative Agriculture, 7(1), 2-3. http://dx.doi.org/10.1017/S0889189300004343

Turner, I. B. L., Skoh, D., \& Sanderson, S. (1995). Land-use\&land-over change. Science/Research Plan IGBPRep No.35, HDP Rep No.7, 1995.

Wang, C. Q., \& Li, T. X. (1997). The discussion about potassic fertilizer resources development and utilization in Ya'an. Bulletin of Soil Agrochemistry, 12(1), 25- 30.

Wang, C. Q., Wei, C. G., \& Li, T. Q. (2001). Different no tillage methods on crop yield and soil physical and chemical properties of influence. Academic Journal of Sichuan Agricultural University, 19(2), 152-154. 
Wang, Y. (1999). Heilongjiang province nursery soil fertility evaluation. Ji Lin Agricultural Science and Technology, 4, 19-21.

WenJiang county soil census office. (1986). soil of Wen Jiang.

Xiao, P. F., Zhang, S. R., \& Deng, L. J. (2005). The space and time variation characteristics of Chengdu PI county recently soil nitrogen nutrient in the procedure of urbanization. Academic Journal of Sichuan Agricultural University, 3(1), 80-84. 